\title{
Ribonucleotide Reductase
}

National Cancer Institute

\section{Source}

National Cancer Institute. Ribonucleotide Reductase. NCI Thesaurus. Code C17101.

Ribonucleotide Reductase is a heterodimeric cytoplasmic enzyme essential in dividing cells that reduces ribonucleotides to deoxyribonucleotide precursors for DNA synthesis in S phase. It consists of two subunits, M1 Chain and M2 Chain. Complex allosteric control, mediated by deoxynucleoside triphosphates, and by ATP bound to the M1 subunit prevents DNA replication and cell proliferation. A substrate specificity site and a catalytic activity site regulate enzyme activity. A substrate-binding catalytic site on M1 is only formed in the presence of M2. Enzyme activity closely correlates with the cellular rate of growth and appears to vary with the cell cycle. $(\mathrm{NCl})$ 